\title{
LISTA RECENZENTÓW \\ „RUCHU PRAWNICZEGO, EKONOMICZNEGO I SOCJOLOGICZNEGO” \\ ZA ROK 2014
}

\author{
Wojciech Cellary \\ Ryszard Cichocki \\ Stanisław Czepita \\ Małgorzata Doman \\ Rafał Drozdowski \\ Stanisław Flejterski \\ Tadeusz Gadkowski \\ Hanna Gerecka-Żołyńska \\ Grzegorz Gołembski \\ Grzegorz Gołębiowski \\ Andrzej Gomułowicz \\ Maciej Gutowski \\ Joanna Haberko \\ Honorata Jakubowska \\ Tomasz Kaczmarek \\ Ryszard Kamiński \\ Zdzisław Kędzia \\ Marian Kępiński \\ Bożena Klimczak \\ Krzysztof Knoppek \\ Cezary Kochalski \\ Katarzyna Kokocińska \\ Jacek Kotus \\ Tadeusz Kowalski \\ Marek Krajewski \\ Janusz Kudła \\ Wojciech Łączkowski
}

Jerzy Małecki

Monika Marcinkowska

Jarosław Mikołajewicz

Tomasz Nieborak

Zdzisław Niedbała

Aurelia Nowicka

Hanna Paluszkiewicz

Jerzy Parysek

Barbara Pogonowska

Łukasz Pohl

Bożena Popowska

Wiesława Przybylska-Kapuścińska

Teresa Rabska

Marek Ratajczak

Tomasz Rynarzewski

Jan Sandorski

Andrzej Skoczylas

Marek Smolak

Tomasz Sokołowski

Tadeusz Stryjakiewicz

Hanna Suchocka

Marek Szewczyk

Paweł Wiliński

Krystyna Wojtczak

Robert Zawłocki

Aldona Żurek 


\section{INFORMACJE DLA AUTORÓW}

1. Objętość nadsyłanych tekstów nie może przekraczać 1 ark. wyd. (36-40 tys. znaków wraz ze spacjami i przypisami) w wypadku artykułu bądź maksymalnie 10 tys. znaków w wypadku recenzji.

2. Teksty należy przesyłać $\mathrm{w}$ formie wydruku oraz $\mathrm{w}$ wersji elektronicznej wraz z nośnikiem lub na adres poczty elektronicznej Redakcji (rpeis@amu.edu.pl).

3. Wszelkie tabele, wykresy lub ryciny będące częścią tekstu należy również przesyłać w formie edytowalnego zapisu elektronicznego. Minimalna grubość linii rysunku powinna wynosić 0,4 pkt, a rysunki należy sporządzić $\mathrm{w}$ wersji czarno-białej, w formacie nie większym niż format kolumny $(126 \times 180 \mathrm{~mm})$.

4. Do artykułu należy dołączyć krótkie streszczenia (abstrakty) w języku polskim i angielskim (ok. 1,5 tys. znaków) oraz słowa kluczowe.

5. Do przesłanego tekstu należy dołączyć dane o autorze, adres do korespondencji, numery telefonów i adres poczty elektronicznej. W wypadku pracowników naukowych prosimy także o podanie nazwy i adresu uczelni macierzystej.

6. Do przesłanej propozycji publikacji należy dołączyć oświadczenie, że przedłożony tekst został nadesłany wyłącznie do Redakcji „Ruchu Prawniczego, Ekonomicznego i Socjologicznego".

7. Termin wykonania korekty autorskiej wynosi maksymalnie 1 tydzień. Po upływie tego terminu tekst kierujemy do publikacji wyłącznie z korektą redakcyjna.

8. Publikacje w kwartalniku RPEiS nie są płatne.

9. Redakcja nie zwraca materiałów niezamówionych.

10. Decyzja Autora o publikacji w RPEiS oznacza zgodę na zarchiwizowanie tekstu w wersji elektronicznej w ogólnodostępnym repozytorium UAM (http://repozytorium.amu.edu.pl) oraz The Central European Journal of Social Sciences and Humanities (http://cejsh.icm.edu.pl), a także na platformie otwartych czasopism naukowych UAM: Pressto (http://pressto.amu.edu.pl).

Szczegółowe zalecenia edytorskie i techniczne dla Autorów znaleźć można na www.rpeis.pl 